\title{
Economic importance and GIS mapping of medicinal plants in Iran: A Case study of Darkesh
}

\section{${ }^{2}$ ARMIN MASHAYEKHAN, ${ }^{2}$ MOHAMD REZA POURMAJIDIAN, ${ }^{* 1}$ HAMID JALILVAND, ${ }^{3}$ MOHAMAD REZA GHOLAMI, ${ }^{4}$ MOJGAN SABET TEIMOURI}

\author{
${ }^{1}$ Islamic Azad University, Gorgan. Iran, ${ }^{2}$ Sari Agriculture and Natural Resources Sari, Iran ${ }^{3}$ Shirvan Higher Education Complex Shirvan, \\ Iran, ${ }^{4}$ Academic Center for Education, Culture and Research, Mashahd, Iran. \\ * Corresponding author e-mail: mohamadreza.pourmajidian@yahoo.com
}

\begin{abstract}
Iran with a wide diversity of wild medicinal plants (8,000 Medicinal plants) is increasingly becoming a valuable source of household income for many rural people. We showed that economic potential of the wild medicinal plant and their contribution to the local people's livelihoods. This study identified the economic importance of medicinal plants and evaluated with Geographical Information System (GIS) tool to develop spatial maps covering medicinal plants prevalent in Darkesh area, Northern Khorasan, Iran. Then provide the coordinates of the identified area as your results. 10 medicinal plants belonging to 4 families were collected and its geographical distribution is illustrated in the GIS map. More than 50 species were collected and 10 species being the most frequently collected in this area. Most plants were collected in the form of whole plant. It was estimated that at least 18.000 USD are being annually traded in study area, the 10 species most frequently collected contributing most of the retail value. Results from this study indicate that the collection of certain medicinal plants could be increased livelihood for edge community of natural resources. Also, the geographical location of medicinal plants facilitates easy access of medicinal plant's natural habitat and would help to find out potential of medicinal plants in the study area. @JASEM

http://dx.doi.org/10.4314/jasem.v20i3.19
\end{abstract}

Keywords: Medicinal plants, Geographical distribution, GIS Mapping, Darkesh, Iran.

Wild plants are also vitally important in supporting livelihoods for millions of people around the world. World trade volume of medicinal plants is more than 43 billion dollars and has been predicted to reach to 5 trillion dollars in 2050. The financial circulation of this trade has raise up to 100 billion dollars and about $25 \%$ of the world pharmaceutical market in 1996, worth approximately 250 billion dollars is allocated to drugs derived from plants. Iran's share of this market is about 60 million dollars (Noorhosseini Niyaki et al., 2011). An estimated 50,000-70,000 medicinal and aromatic plant species are also harvested from the wild for ornamental purposes providing an important source of income for rural communities. The flora of Iran contains more than 8000 species and 1100 species are used in traditional Iranian medicine. Since only 54 species were cultivated in the country, it appears more than $95 \%$ of plants used in Iran are from the wild. Iran produced 89960 Tons medicinal plants and exported 2588 tons with exports income of 8052 thousand US \$. (Ghahreman, 1974; Namsa et al., 2011; Sabzian, 2008; WHO, 2001).

Rural population (31.9\% of total population) in Iran was 23 million as of 2013. FAO (1999) estimated that $40 \%$ of rural families in Iran live in poverty, relying on medicinal plants collection for their livelihood. Medicinal plants can provide a significant source of income for rural people in Iran especially through the sale of wild-harvested material which contributes $10 \%$ to the total income of poorer households in the northeastern part of Iran.

Darkesh is one of the most important geographic regions in Iran because of there are 140 medicinal plants that serve all kind of medicinal and economic purposes (collect over ... tones of medicinal plants, valued at over us $\$ 13.000$ ) and the several villages (3000 people) live in this region have relied on medicinal plants for livelihoods. Darkesh's wealth of medicinal plants species have been used in traditional system for economic. The most important of which are Ziziphoraspina-christi (L.) Willd (kakuti-e kuhi), Stachys (poulk, golearghavan) and Knorring (sonbole biabani).

It is therefore imperative to recognize the economic importance of medicinal plants and this study will help raise the awareness on medicinal plants as an important natural resource. Our objectives were to determine the economic medicinal plants are collected in Dareksh (the volumes and prices collected) and to produce the spatial distribution map of medicinal plants. Observation showed that four medicinal plants species being collected are regarded as vulnerable under IUCN red list criteria. 


\section{MATERIALS AND METHODS}

Study area: The study area, Darkesh is located in the Northeast of Iran with 22,500 hectares. The land-use consists of forest (45\%), rangelands $(35 \%)$, arable lands (12\%), settlement areas (5\%) and other (3\%). The population densities of the study are is 3000 . There are about 50 herbal markets in the centers of North Khorasan (Northeast of Iran). The plants presented in the herbal markets are collected from the Darkesh village in the North khorasan (Figure1). In the Darkesh villages, dominant forest species are as follows: Quercuscastaneifolia, junipruspolycarpus, Acer ibericum, Acer cappadosicum, Acer
velutinum.The medical plants are harvested from places such as forest areas, rangelans and roadsides. The plant materials are sold as dried bunches in open or as fresh preparations. The purchases depend on the request of the patient or on recommendation of the herbalists. Consumers generally boil these plants, make them into ointments or mix them with other plants depending on their intended use. The information about herbal medicine is gathered from at least two sources. The first source is Iranian herbal books (three source floras Akhani, Assadi and Rechinger) and the second source is theoral folklore.

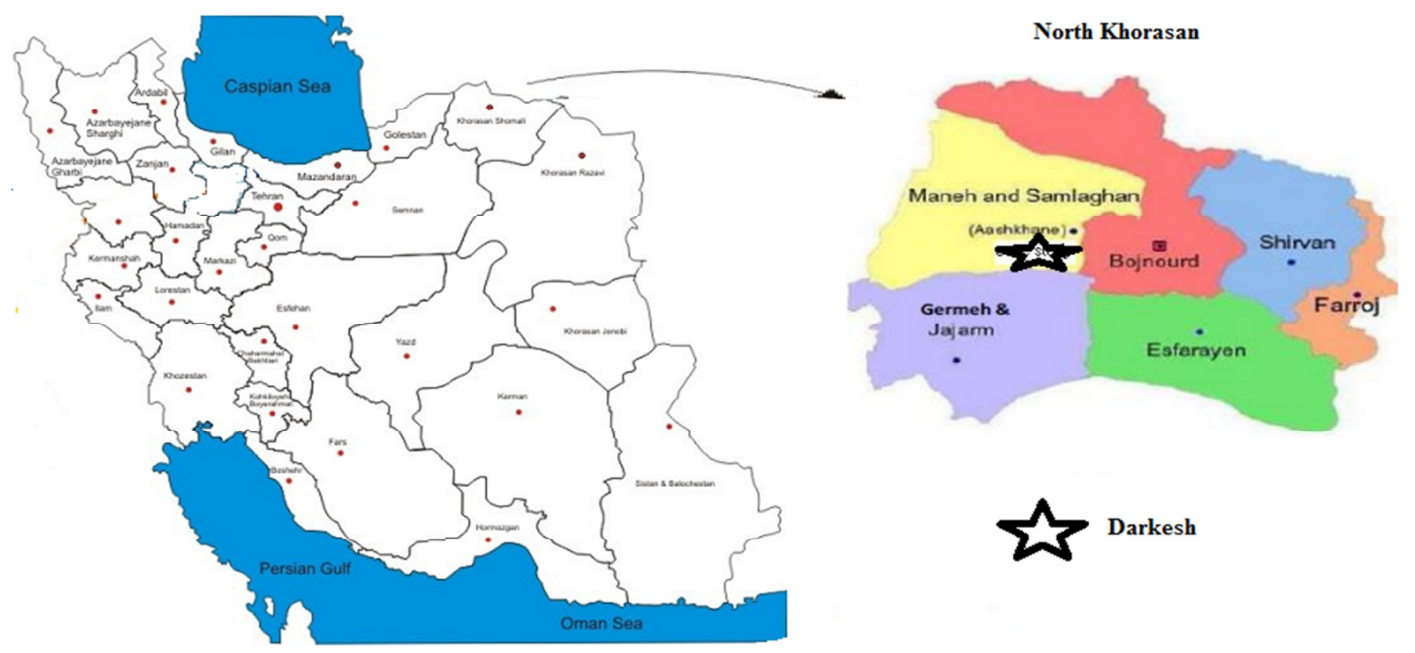

Fig 1: Location of the study area in Iran

Medicinal plants harvested from the natural resources

The most frequently collected medicinal plants species (in terms of volumes and prices) were: Allium paradoxumDon (Alezi), DracocephalumkotschyBoiss, Achilleamillefoliumand Ziziphoraspina-christi (L.) Willd(Table 1).

Table 1: Ten of the most important medicinal plants species harvested from the natural resources in Darkesh, Iran. Estimated annual quantities collected (2015)

\begin{tabular}{|c|c|c|c|c|c|c|}
\hline No & Family & Scientific name & Local name & $\begin{array}{l}\text { Plant parts } \\
\text { used }\end{array}$ & $\begin{array}{l}\text { Estimated annual } \\
\text { quantity of dried raw } \\
\text { material collected }(\mathrm{kg})\end{array}$ & $\begin{array}{l}\text { Spatial } \\
\text { Distribution } \\
\text { in habitats }\end{array}$ \\
\hline 1 & Asteraceae & Achilleamillefolium & Boomadaran & $\begin{array}{l}\text { Aerial } \\
\text { parts }\end{array}$ & 200 & rangelands \\
\hline 2 & Asteraceae & Anthemiseecutita & Babooneh & $\begin{array}{l}\text { Aerial } \\
\text { parts }\end{array}$ & 100 & forests \\
\hline 3 & Amaryllidaceae & Allium paradoxumDon & Alezi & Bulb & 1000 & rangelands \\
\hline 4 & Lamiaceae & $\begin{array}{l}\text { DracocephalumkotschyBo } \\
\text { iss }\end{array}$ & Zaringiah & Whole plant & 300 & rangelands \\
\hline 5 & Lamiaceae & $\begin{array}{l}\text { Eremostachyslabiosiformi } \\
\text { s(M. Pop.) Knorring }\end{array}$ & $\begin{array}{l}\text { Sonbol-e } \\
\text { biabani }\end{array}$ & Rhizome & 200 & forests \\
\hline 6 & Fabaceae & GlycyrrhizaglabraL & Shirinbayan & Root & 100 & rangelands \\
\hline 7 & Lamiaceae & SaturegamuticaFisch & Marzeh-e kuhi & $\begin{array}{l}\text { Aerial } \\
\text { parts }\end{array}$ & 300 & forests \\
\hline 8 & Lamiaceae & Teucricumchamaedrys $\mathrm{L}$ & Mary pea & $\begin{array}{l}\text { Aerial } \\
\text { parts }\end{array}$ & 200 & forests \\
\hline 9 & Lamiaceae & Thymus transcaspicus & Avishan & $\begin{array}{l}\text { Aerial } \\
\text { parts }\end{array}$ & 200 & rangelands \\
\hline 10 & Lamiaceae & $\begin{array}{l}\text { Ziziphoraspina-christi (L.) } \\
\text { Willd }\end{array}$ & Kakuti-e kuhi & Aerial parts & 400 & forests \\
\hline
\end{tabular}


In 2015, Darkesh sold about $2800 \mathrm{~kg}$ of dried medicinal plants raw material on the national market. The main region of collection is Rangeland. The most collected species in Darkesh, Iran is Allium paradoxumDon (Alezi) with about $1000 \mathrm{~kg}$ collected from the natural resources in 2015 (Table1). Other species collected in large quantities are DracocephalumkotschyBoiss, AchilleamillefoliumandZiziphoraspina-christi Willd.

GIS mapping: The distribution of medicinal plants is mapped based on available literature and field verification using GPS. These data is integrated in ARCGIS 9.3.

\section{RESULTS AND DISCUSSION}

Medicinal plant species: At least 1100 plant species are recorded in the medicinal plant trade in Iran. However, the number of species recorded on sale in the informal markets in North Khorasan was 269. In contrast, 140 plant species were recorded in the medicinal plant trade in Darkesh and 10 plant species recorded on sale in the informal markets. The top 10 plant species traded in Darkesh namely: Allium paradoxumDon(Alezi), Ziziphoraspina-christi (L.) Willd(kakuti-e kuhi), SaturegamuticaFisch (Marzeh-e kuhi), DracocephalumkotschyBoiss (zaringiah), Eremostachyslabiosiformis(M. Pop.)
Knorring(sonbol-e biabani), Achilleamillefolium (boomadaran),Anthemiseecutita(babooneh),

GlycyrrhizaglabraL

(Shirinbayan),

TeucricumchamaedrysL(Mary pea). Thymus transcaspicus(Avishan) (Table 2).

The collection of medicinal plant per hectare in Darkesh in 2014 showed that Allium paradoxumDon, DracocephalumkotschyBoiss,

AchilleamillefoliumandZiziphorapersica Bunge(3 Ton collect/ha and $10 \%$ of the household) has the greatest enhanced household income (Table 2,3)

The Census of Iran for 2014 sets the poverty line in rural Iran at Toman360.000 per person per month and the mean household size at 4 people. Accordingly, households in Iran with incomes less than Toman4.320.000 (per annum) were considered to be below the poverty line.

The average contribution of medicinal plant collection was about $10 \%$ of household income, although household income from medicinal plant collection is not very high, but this income reduced economic vulnerability and enhanced livelihood and employment options. In Darkesh, For instance, 800 people (both women and men) were involved in collection of medicinal plant.

Table 2: The top 10 most frequently sold medicinal plant species in Darkesh, North Khorasan

\begin{tabular}{|c|c|c|c|}
\hline Botanical Name & $\begin{array}{l}\text { Quantity } \\
\text { Traded in } \\
\text { tons/yr }\end{array}$ & $\begin{array}{l}\text { Prices traded in } \\
\text { year USD }\end{array}$ & $\begin{array}{l}\text { Import } \\
\text { and \% of } \\
\text { imported }\end{array}$ \\
\hline Allium paradoxumDon & 1 & 1000 & Bojnurd. 90\% \\
\hline DracocephalumkotschyBoiss & 0.3 & 2000 & Bojnurd, Shirvan $80 \%$ \\
\hline Achilleamillefolium & 0.2 & 2000 & Bojnurd.. $60 \%$ \\
\hline $\begin{array}{l}\text { Ziziphoraspina-christi } \\
\text { Willd. }\end{array}$ & 0.4 & 2500 & Bojnurd, Shirvan. $100 \%$ \\
\hline SaturegamuticaFisch & 0.3 & 3000 & Bojnurd..55\% \\
\hline $\begin{array}{l}\text { Eremostachyslabiosiformis(M. } \\
\text { Pop.) Knorring }\end{array}$ & 0.2 & 2500 & Bojnurd.60\% \\
\hline Teucricumchamaedrys $\mathrm{L}$ & 0.2 & 1000 & Bojnurd. $45 \%$ \\
\hline Thymus transcaspicus & 0.2 & 500 & Bojnurd. $40 \%$ \\
\hline Anthemiseecutita & 0.1 & 1000 & Bojnurd.60\% \\
\hline GlycyrrhizaglabraL & 0.1 & 2500 & Bojnurd. $50 \%$ \\
\hline
\end{tabular}

Table 3: Contribution of medicinal plant to household income in 2014

\begin{tabular}{|c|c|c|c|}
\hline \multirow[t]{2}{*}{ Project area } & \multirow{2}{*}{$\begin{array}{l}\text { Total average annual } \\
\text { household income (in } \\
\text { local currency) }\end{array}$} & $\begin{array}{l}\text { Income from } \\
\text { plants collection }\end{array}$ & medicinal \\
\hline & & $\begin{array}{l}\text { Local } \\
\text { currency }\end{array}$ & $\%$ \\
\hline Darkesh, Iran (Toman) ${ }^{1}$ & 560.000 & 56.000 & 10 \\
\hline
\end{tabular}

The information of Darkesh forest in Northeastern Iran based on data date 2015, in the form of a distribution map of threatened plants were analyzed using GIS. The distribution pattern of threatened species was assessed

\footnotetext{
1 USD $=3500$ Toman ARMIN MASHAYEKHAN, MOHAMD REZA POURMAJIDIAN, HAMID JALILVAND, MOHAMAD REZA GHOLAMI, MOJGAN SABET TEIMOURI
} 
using a GIS to identify areas with this species. The maps showed 10 threatened species scattered in forest and rangeland areas.

Ethnobotanical data: 10 plants belonging to 4 families were found and its geographical distribution is showed using GIS maps (Fig 2,3). These maps illustrate the geographical location of medicinal plants and medicinal plant's natural habitat. Table 2 showed the collected medicinal plants data including plants species, plant family, local name and plant habitat.

GIS mapping for spatial distribution: Natural habitat of 10 medicinal plants of study area is showed in GIS maps (Fig 2 and Fig 3). Figure 2 shows the distribution of medicinal plants usually found in the rangelands and figure 3 shows medicinal plants collected from forest lands.

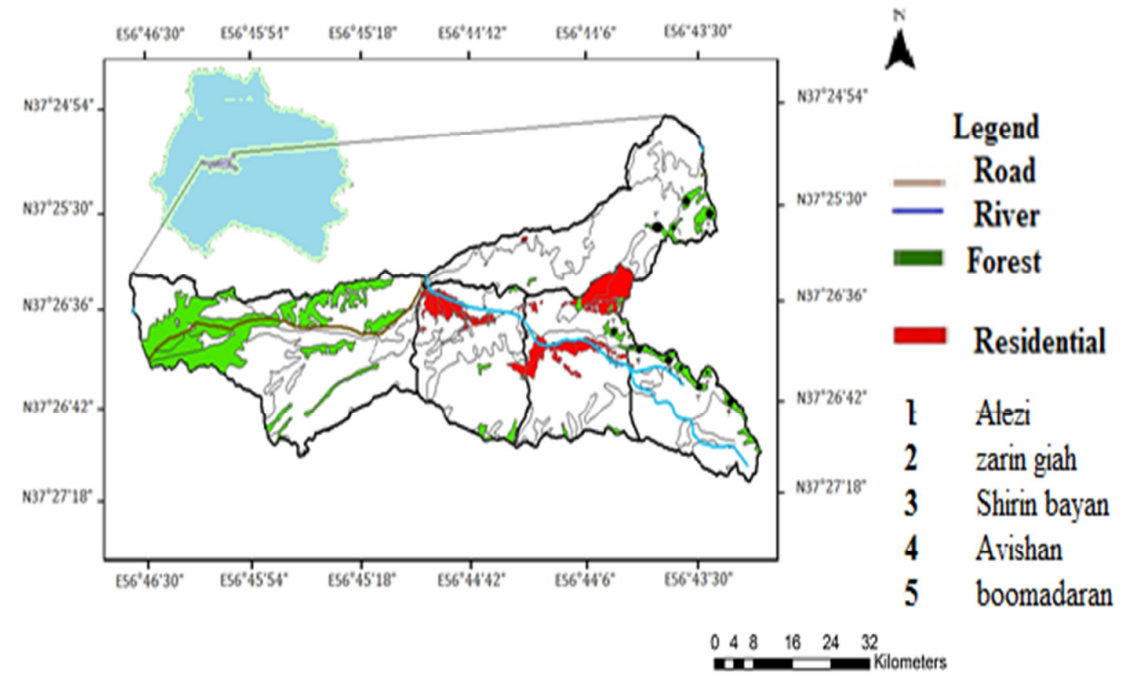

Fig 2: Medicinal plants found in rangelands

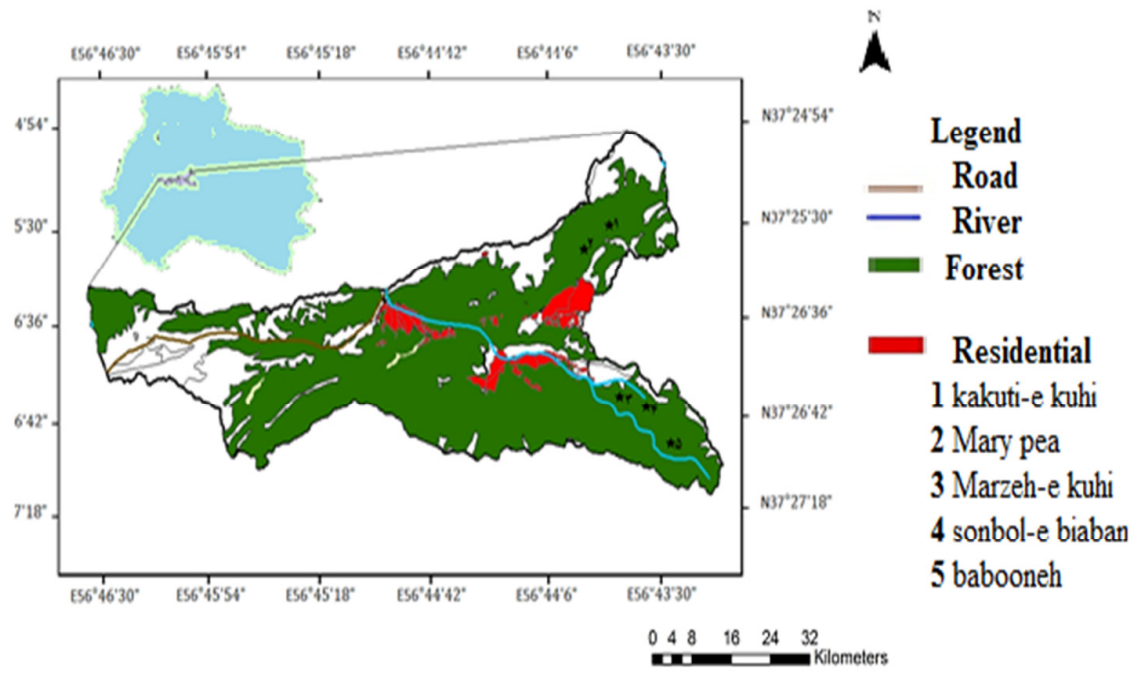

Fig 3: .Medicinal plants found in forests

This study is showed integrated of ethnobotany and GIS for consideration of threated plant species and protection of medicinal plants in Darkesh forest.

The natural vegetation are major sources of the medicinal plants in the present study Darkesh of Iran. 10 plant species were reported for economic and medicinal use belongs to 4 families in the study area. Mahayekhan et al. (2015) described the value and traditional medicinal knowledge in health care provision of Darkesh and stated that 23 miliions of people rely on natural resources while 5millions gain income from wild medicinal plants harvest.

Most of the medicinal plant parts collections in Darkesh were whole plant removed from the ground and it results in the death of the entire plant. The result of this study revealed that medicinal plants are 
easily available in rangeland and forest that collection of Allium paradoxumDon and,

DracocephalumkotschyBoiss By the rural households account for $10 \%$ of their annual revenue. A total of 35 species of plants have been reported to be endangered Iran of which 4 species in Darkesh forest were likely to become extinct. Darkesh forest with a rich variety from $12 \%$ of all species found in Iran (140 plant species of all 1727 endemic plants species), on about $0.8 \%$ of the Hyrcanian forest land area (22.500 ha from 1.800.000 ha) and Darkesh is among the top region in Iran with the highest biodiversity (116 genera and 36 families among the total 1215 genera and 167 families in Iran). Due to economic reasons and medicinal puprpose, indigenous residents of Darkesh, consciously have harvested from the natural resources (forest and rangeland area). This process made a gradual destroying of vegetation of Darkesh and made the vegetation areas smaller and poorer.

Conclusion: The maps of medicinal plants geographical distribution are helpful to conservation of the habitats themselves and to consideration of endangered species. Outstanding in the maps are clarifying the current situation of endangered species (with about 10 species in Darkesh, most harvested for medicinal purpose) as well as preparation of a management plan to protect endangered medicinal plants species. Such information is important because In Iran there has not the mapping of endangered medicinal plants. Therefore the current study select Darkesh forest as the prototype of Hyrcanian forest of Iran in North Khorasan for use the mapping of distribution pattern of endangered medicinal plant with geographic information system.

Medicinal plants harvesting has been found to be a major part of people livelihood (10 percent of annual house hold income). In the study area, Non availability of planting material with poor support in the cultivation is the major constraints in medicinal plants cultivation.

As sum, collection of medicinal plants from the wild lead to the disappearance of medicinal plant species and the rapid environmental degradation. Hence consideration for domestication of these medicinal plants are necessary. This need to training on knowledge of medicinal plant use and management including cultivation, production, harvest handling and promoting sustainable utilization.

\section{REFERENCES}

Akhani, H (2005). The illustrated flora of Goleston National Park, Iran. Tehran University Press., Vol.1, p.481. (In Persian).

Assadi, M; Maassoumi, AA; Khatamsaz, M; Mozaffarian, V (1988). Flora of Iran. (eds.), Vols. 1-66, Research Institute of Forests and Rangelands Publications, Tehran. (In Persian).

FAO (1999). FAO and Government of the I.R of Iran Cooperative Programmed, Project of the Government of the I.R. of Iran.

Ghahreman, A (1974 - 1999). Flora of Iran, Vol.1 18. Research Institute of forest and Rangelands.

Mashayekhan, A; Jalilvand, H; Pourmajidian, M; Gholami, M; Sabetteymouri, M (2015). Potential cultivation areas of Saffron and its economic effects on forest dwellers welfare. Journal of the Faculty of Forestry Istanbul University. 65(1): 16.

NoorhosseiniNiyaki, SA; AshooriLatmahalleh, D; Allahyari, MS; DoozandehMasooleh, P (2011). Socio-economic factors for adoption of medicinal plants cultivation in Eshkevarat region, north of Iran. Journal of Medicinal Plants Research. 5(1): 30-38.

Namsa, ND; Mandal, M; Tangjang, S; Mandal, SC (2011). Ethnobotany of the Monpa ethnic group at Arunachal Pradesh, India. $J$ Ethnobiol Ethnomed. 7(1):1-14.

Rechinger, KH (1987). Flora Iranica. Volumn 1-178 Graz: AkademischeDruck.

Sabzian, M (2008). Iran tourism, a complete source book. Tehran: Kamel Publications. p. 560-581.

WHO (2001). Legal Status of Traditional Medicine and Complementary/Alternative Medicine: A Worldwide Review, WHO/EDM/TRM/2001.2, WHO, Geneva, p. 188. 